\title{
Identity, impoliteness and integration in online immigration discourse
}

\author{
Tożsamość, niegrzeczność i integracja \\ $\mathrm{w}$ internetowym dyskursie imigracyjnym
}

Anna BĄCZKOWSKA ${ }^{1}$

University of Gdańsk

Ljiljana ŠARIĆ

University of Oslo (Norway)

\begin{abstract} Poles is imbued with insults, negative associations and derogatory nominations.

Keywords: identity, impoliteness, immigration discourse

1 https://orcid.org/0000-0002-0147-2718

University of Gdańsk, Institute of English and American Studies,

English Language and Theoretical Linguistics Division anna.baczkowska@ug.edu.pl

2 . https://orcid.org/0000-0003-4373-9182

University of Oslo, Norway

Department of Literature, Area Studies and European Languages

ljiljana.saric@ilos.uio.no
\end{abstract}

The paper presents an analysis of the language used on the Internet (social media) by Poles living in Norway. Emphasis is placed on identity construction, integration and impoliteness strategies. The material presented in this study was retrieved from a corpus which was collected as part of a project devoted to national identity in immigration discourse. The method of analysis presented in this paper follows Culpeper's (1996) taxonomy of impoliteness strategies. The data under inspection illustrate several types of positive and negative impoliteness. The results of the study demonstrate that the Polish diaspora in Norway is only partially integrated and that the language Poles use while writing both about the Norwegians and, in particular, about other 
Streszczenie

Celem artykułu jest opis dyskursu używanego w mediach społecznościowych przez Polaków mieszkających w Norwegii. W celu przeprowadzenia analizy utworzono korpus danych zebranych z mediów społecznościowych, w przeważającej mierze z forów internetowych prowadzonych przez Polaków. Korpus ten utworzono w ramach projektu poświęconego badaniu tożsamości narodowej $\mathrm{w}$ dyskursie imigracyjnym. Badanie ukierunkowane było na wyszukiwanie wypowiedzeń świadczących o wyłaniającej się tożsamości polskich imigrantów w Norwegii, na identyfikacji używanych przez nich strategii integracji z ludnością rdzenną oraz na analizie języka, którego używają wypowiadając się na forach na wspomniane tematy. Język badany był pod kątem używania strategii niegrzeczności przez uczestników forów internetowych w oparciu o taksonomię zaproponowaną przez J. Culpepera (1996). Przeprowadzona analiza wykazała istnienie jedynie częściowej integracji polskich imigrantów z Norwegami oraz wyłanianie się trzech typów tożsamości. Na poziomie analizy języka zidentyfikowano kilka rodzajów pozytywnej i negatywnej niegrzeczności (positive/negative impoliteness). Zaobserwowano wysoką okurencję wypowiedzi przesiąkniętych obelgami, negatywnymi skojarzeniami i obraźliwymi nominacjami skierowanymi do przedstawicieli polskich imigrantów w Norwegii.

Słowa kluczowe: tożsamość, niegrzeczność, dyskurs imigracyjny

\section{Introduction and theoretical preliminaries}

This analysis ${ }^{3}$ concentrates on online discourse and is based on texts written by Polish immigrants to Norway. The material was collected from the internet, primarily from several online forums run by Poles living in Norway, yet occasionally extracts from blogs and comments to articles are also referred to. The method of data analysis follows Culpeper's (1996) taxonomy of impoliteness strategies.

This section will provide an overview of relevant research, as well as some theoretical considerations related to the concepts important for this analysis, including specific features of online communication, and the connection between immigration discourse, identity construction and impoliteness. Section 2 presents the data collection and method, Section 3 is devoted to data analysis, and Section 4 provides concluding remarks.

\subsection{Computer-mediated communication}

Online communication, by and large, is characterized by a number of features that share elements of both spoken and written discourse. Even outside

\footnotetext{
${ }^{3}$ This article is part of research activities of the project Discourses of the Nation and the National, based at ILOS, University of Oslo. The research was funded by the project.
} 
of the computer-mediated communication (CMC) provenance, often, the clear divide between what makes a spoken discourse vs. written discourse is claimed to be hazy, blurred and misleading (McCarthy 1993: 180). Interestingly, contrary to popular views and expectations of online discourse being a closer representation of the spoken discourse, rather than staying mid-way, research conducted by Yates (1996) proves that online discourse, on the textual level, shares affinities with the written language. This observation confirms the statement put forward much earlier by Crystal (2001: 42-43) regarding the nature of web discourse (which he proposed to call Netspeak).

The language used in CMC is characterized by diversity (email correspondence, for example, ranges from very formal to very informal): it is influenced by variables such as the purpose of interaction (e.g. an official invitation versus a private one), gender, age, status of participants, etc. (Herring 2007 and Androutsopolous 2006 stress a shift of focus from medium-related to user-related patterns of language use, which brings a variety of group practices to the centre of attention).

The debate about social media and their role develops around two questions: do social media enable greater cross-cultural sharing by allowing people access to information and frequent participation in public life, or do they lead to disengagement. Existing research provides different answers (see Bouvier 2015 for an overview). Although people use social media for personal identity construction, and frame events into some pre-existing personal interests, they still contribute information of civic relevance (see Hilbert 2009).

\subsection{Immigration discourse, identity construction and the role of impoliteness}

Immigration discourse per se has already been an object of extensive research. Several important publications have come out on immigration discourse (e.g. van Dijk 1984, 1987, 1991; van Leeuwen and Wodak 1996; Wodak 1996), yet not on Polish immigration in Norway.

Racism, ethnicism and discrimination are some of the topics analysed in the context of immigration. In the multidisciplinary account of theoretical as well as empirical developments in the field of Critical Discourse Analysis (CDA), edited by Hart and Cap (2014), Richardson and Colombo (2014) describe racism encoded in both verbal and visual elements found in selected political leaflets. T. van Dijk (2015) summarizes research devoted to racism conducted since the eighties within the theoretical framework of CDA, where he notes that three main areas of research can be identified: firstly, studies into 
immigration seen as an integration problem of the minority presented in newspapers; secondly, studies into political discourse related to immigration; and finally, immigration presented in educational context (e.g. textbooks). Reisigl and Wodak (2001) provide us with a discourse-analytical approach to texts where the three key concepts mentioned above are latent; they show us how to unmask the discriminatory meanings hidden in texts by means of five discursive strategies. These strategies are as follows: (1) Nomination or reference: looks at how social actors, objects, phenomena and events are named and referred to linguistically; (2) Predication: examines characteristics and features attributed to the actors, objects and phenomena; (3) Argumentation: justifies truth claims and often relies on topoi (part of argument schemes that can connect the premise of an argument to its conclusion); (4) Perspectivization: positions the point of view of the producer of a text; (5) Intensification or mitigation: modifies the force and status of utterances. These strategies can be part of broader macro-strategies (e.g. misrepresentation, (de)legitimation).

Immigration discourse has been pursued in different national contexts. For example, the Hispanic context of immigration discourse has been expounded by Martínez Lirola (2013), the context of Austrian immigration was examined by Krzyżanowski and Wodak 2009, the construction of French and British immigration was delineated by Raymond and Modood (2007), the European identity discourse was sought by Krzyżanowski (2010), while Dikötter (1997) explored the concept of the construction of racial identities in China and Japan.

Methodologically, immigration discourse has been sought with the aid of several schools within the paradigm of CDA, or a combination of them. For example, Wodak's discourse-historical approach, Leeuwen's socio-semantic approach and van Dijk's socio-cognitive approach have been successfully merged and applied to the analysis of the British press by KhosraviNik (2010, 2014). Hart (2011, 2015), on the other hand, proposes fusing CDA with cognitive linguistics and construal operations.

Immigration discourse opens many questions of self- and otherperceptions. Immigration as a phenomenon involves continuous (re)definitions of identity and membership in a community. Studying immigration discourse (specifically, discourse by immigrants, be it their stories or other genres) aids developing knowledge about self-perception and identity formation among immigrants, and may lead to a better understanding of the factors that help immigrants either to integrate or contribute to their isolation within the host society. Immigration discourse reveals valuable data about immigrants' complex 
links to their home countries and host societies, giving insight into communities that are often subject to stereotyping. A discursive approach to identity in immigration discourse may focus on how the self is presented in connection with others and in relation to social experiences. De Fina (2003) analyzes these issues in a qualitative view on immigrants' narratives by looking at pronominal choices and voicing. Further, de Fina looks at the central identification category for self and others, which is, according to her, ethnic identification ("Hispanic" in her analysis).

While this paper hinges on the linguistic theoretical framework, it would be a major omission not to mention publications devoted to Polish immigration offered by other fields of knowledge, which provide a useful social and political bedrock for any linguistic analysis of immigration discourse. An insightful report on the state of the art of Polish immigration in Norway has been put online recently. The report is the outcome of a conference organized by the Polish Ministry of Foreign Affairs in Oslo, in November $2015^{4}$. The publication has been prepared jointly by Polish and Norwegian scholars and practitioners representing various branches of business. So far, it seems to be one of the most recent and comprehensive accounts of the current situation of Polish immigration to Norway after the accession of Poland to the EU. An anthropological standpoint, on the other hand, on Polish immigrants in Oslo has been presented by M. Pawlak in his doctoral thesis (2012). A meticulous sociological study on how Polish immigration has evolved in Norway over the last seven decades has been offered by E. Olszewski (2011).

Not much research on CMC has focused on (im)politeness. This topic is central to the special issue edited by Locher (2010), who considers the following dimensions crucial in the relation between (im)politeness research and CMC: (a) written records of the negotiations of norms found online (interactants publicly discuss violations of expectations); (b) how interpersonal issues are negotiated in online interaction, how they relate to identity construction and the negotiation of face; and (c) specific restrictions that the medium of CMC imposes on relational work/facework, and its consequences for linguistic choices.

In one of the few studies thematizing explicitly CMC, identity and impoliteness (concentrating on online comments) Upadhyay (2010) concludes that interactants use impoliteness to communicate disagreements, to argue against an outgroup's views, and to discredit (ideological) opponents. By using impoliteness the interactants identify themselves as individuals whose views

${ }^{4}$ Available at: http://oslo.msz.gov.pl/resource/0c005e6b-1a8e-4184-a454-deabde543fad:JCR 
are opposed to those of outgroup members. Impoliteness constitutes them as social agents promoting a belief held by ingroup members. In line with Herring (2007), Upadhyay (2010) suggests a link of anonymity and antisocial behaviour/impoliteness; Donath (1997) emphasises the possibility of online communication being antisocial. Nishimura (2008) indicates that impoliteness could potentially destroy an online community.

Scarce research on impoliteness in online discourse shows that impoliteness plays a role in negotiating cultural and community norms and constructing (un)desirable group and individual identities. As Garcés-Conejos Blitvich (2010) proves by analysing YouTube comments, positive impoliteness strategies $^{5}$ may create a strong sense of us versus them, intensify in-group cohesiveness and reinforce its delimitation from the out-group by evaluating the attributes linked to the out-group as undesirable. In addition to fostering polarization, impoliteness can significantly contribute to the construction of collective identities. Impoliteness creates an excluding sense of us versus them by systematically attacking and delegitimizing others' points of view, beliefs, attitudes and behaviour patterns. Analysing CMD, specifically, two academic online discussion fora, Angouri and Tseliga (2010) indicate that strategies associated with impoliteness are used to express strong disagreement and to aggravate face-threatening acts. They demonstrate that different microstrategies in and of themselves do not account for instances of impoliteness; evaluations of impoliteness relate to different factors, such as conversation topic and participants' identity.

Disagreement is a rich area for the study of marked behaviour, including impoliteness. It entails opposing views, and the escalation of disagreement can potentially culminate in the breaching of norms of "appropriate" behaviour and be negatively evaluated by the participants. Disagreement does not necessarily involve language use that may be perceived by the interactants as impolite. Rather, it can challenge the boundaries of "politic" or appropriate linguistic behaviour when it includes conflictual interactions (Graham 2007, Norrick and Spitz 2008).

\footnotetext{
${ }^{5}$ Strategies designed to damage an addressee's positive face wants by, for example, excluding him or her, being disinterested, using taboo words etc. Negative impoliteness refers to strategies designed to damage an addressee's negative face want by being condescending, frightening the addressee or invading the addressee's space.
} 


\subsection{Impoliteness and impoliteness strategies}

Although it was Culpeper (1996) who introduced the topic of impoliteness into the wider academic discussion, other approaches to impoliteness have also been developed, notably by Bousfield (2008). Despite its popularity as a methodological tool applied to studies anchored to varying cultural, linguistic and social contexts over the last twenty years, Culpeper's taxonomy of impoliteness strategies has received a lot of critical comments from a number of scholars. For example, as Bousfield notices, Culpeper claims that his model is open-ended, viz. the strategies can be enriched to include other possible examples of interactions. This flexibility of the model, according to Bousfield, may be its weakness as it lacks a clear-cut set of finite strategies, and with the whole inventory of possible examples, the model might be "impervious to counterexamples". Bousfield (2008: 92) also sees inconsistency in the new impoliteness model proposed by Culpeper (2005), as the new definition of "positive impoliteness" does not seem to be convergent with all strategies which instantiate it. Moreover, Bousfield criticizes Culpeper for the excessive reliance on Brown and Levinson's typology of politeness in the sense that in both Brown and Levinson's politeness theory and Culpeper's impoliteness theory the analyses are decontextualised (Bousfield, 2008). Culpeper (2016) admits that his later redefinitions of impoliteness did not rely so much on Goffman's concept of face and allowed other cases to arise (for example, by depriving others of their rights rather than deliberate face-inflicting behaviour).

Importantly, Culpeper (2016: 428) acknowledges, following a critique of his strategies expounded by some other scholars, that the strategy "bold on record impoliteness" is difficult to distinguish from both positive and negative impoliteness and that this problematic category has been inadequately exemplified in his study (1996); as a result, it is questionable. Likewise, some other strategies and superstrategies are challenged on the grounds of being unclear or overlapping. Further to that, Culpeper agrees with Blas Arroyo (2001: 22 in Culpeper 2016) who notices that the criteria used in Culpeper's taxonomy are inconsistent: while some relate to purely linguistic and discourse-oriented aspects, others involve physical or interactional behaviour. The fluidity of his taxonomy is openly admitted by Culpeper (2016: 428), who states that "it is absolutely the case that one and the same strategy can often be viewed from different perspectives" and, with respect to positive vs. negative face, that "much depends on how the research orients to those categories" (Culpeper 2016: 442). On the other hand, Culpeper (2011: 255-256) 
also emphasises that impoliteness formulae and strategies are not isolated but contextualised in impoliteness events, and thus he disagrees with Bousfield's criticism mentioned above.

An important factor pertinent to the study of im/politeness is the notion of intentionality, as well as the recognition of intention which relates to rudeness. Culpeper (2005) admits that in his early definition of impoliteness intentionality was the key concept: impoliteness occurs when the sender is intentionally impolite (attacks the addressee's face) and the hearer perceives the intentionality of the sender's face attack (2005: 38). This requirement of intentionality was later cancelled by Culpeper himself. After all, one may be unintentionally impolite or impoliteness could not be assessed by the addressee as such. These observations have shifted the centre of gravity in impoliteness studies onto the addressee by suggesting that impoliteness should be analysed solely from the perspective of the receiver. The redefined version of the concept emphasizes not only the role of the addressee but also the notion of expectancy, i.e. impoliteness takes place when there is a conflict between the current behaviour of the sender and what one expects, wants or thinks should be said or done (Culpeper et al. 2003; Culpeper 2011: 254).

The notion of expectancies relates Culpeper's recent research to Kádár and Haugh (2013) views: the authors see im/politeness as a social practice implying that im/politeness does not relate to a particular linguistic form per se. Instead, $\mathrm{im} /$ politeness resides in evaluations of those forms in a social setting. It arises through evaluations of social actions and meanings. These evaluations are rooted in a moral order (Kádár and Haugh 2013: 73, 251).

The issue of intentionality, or lack of it, in the context of juxtaposing impoliteness with rudeness, has been taken up, inter alia, by Bousfield (2010) and Terkourafi (2008). While Bousfield proposes a set of criteria used to distinguish between the two notions, Terkourafi associates impoliteness with unintentional and rudeness with intentional face aggravation.

Interestingly, Watts (1989) drifts away from the dichotomous division between what is polite and what is impolite and in lieu of these notions, understood as mutually exclusive, he proposes a tripartite typology encompassing three types of behaviour - politic, non-politic and polite whereby more fluidity is allowed between politeness and impoliteness (interpretation is based on marked vs. unmarked behavior). Terkourafi (2008) takes one step further and suggests a unified theory to engulf not only impoliteness and rudeness but also to combine them with the notion of politeness. This approach only shows how fluid and difficult it may be for researchers to capture these concepts. Notwithstanding past and current 
discussion, a clear dividing line between impoliteness and rudeness remains difficult to pinpoint.

Despite the criticism expressed on Culpeper's taxonomy of impoliteness and some adjustments introduced to the model by Culpeper himself, it still remains a very influential proposal. The method of analysis used in this paper follows thus Culpeper's (1996) taxonomy of impoliteness strategies, as the critical comments expressed about impoliteness classification, notably by Bousfield, do not seem to be relevant for our study, and the taxonomy per se presents the problem of impoliteness in a comprehensive and concise way. The strategies presented in our analysis are illustrative of both positive and negative impoliteness; however, not all strategies proposed by Culpeper are fully represented in our data. This is partially due to the fact that the data illustrate web-based type of interaction, where replies are delayed, the participants are deprived of non-verbal behaviour and the whole load of information is packed in the verbal mode, occasionally accompanied by emoticons, which makes the material under scrutiny different from other types of data analysed by impoliteness theorists (e.g. face-to-face interaction). The linguistic capacity in online interaction is thus crucial due to technical constraints of the medium of communication (including both space and time restrictions). The template for the present analysis is therefore as follows (cited after Culpeper 1996: 357-358):

Positive impoliteness strategies

1. Ignore, snub the other - fail to acknowledge the other's presence.

2. Exclude the other from an activity.

3. Disassociate from the other - for example, deny association or common ground with the other; avoid sitting together.

4. Be disinterested, unconcerned, unsympathetic.

5. Use inappropriate identity markers - for example, use title and surname when a close relationship pertains, or a nickname when a distant relationship pertains.

6. Use obscure or secretive language - for example, mystify the other with jargon, or use a code known to others in the group, but not the target.

7. Seek disagreement - select a sensitive topic.

8. Make the other feel uncomfortable - for example, do not avoid silence, joke, or use small talk.

9. Use taboo words - swear or use abusive or profane language.

10. Call the other names - use derogatory nominations. 
Negative impoliteness strategies

1. Frighten - instill a belief that action detrimental to the other will occur.

2. Condescend, scorn or ridicule - emphasize your relative power. Be contemptuous. Do not treat the other seriously. Belittle the other (e.g. use diminutives).

3. Invade the other's space - literally (e.g. position yourself closer to the other than the relationship permits) or metaphorically (e.g. ask for or speak about information which is too intimate given the relationship).

4. Explicitly associate the other with a negative aspect - personalize, use the pronouns ' $I$ ' and 'you'.

5. Put the other's indebtedness on record.

\section{Data collection and method}

\subsection{Data collection}

As our data come largely from forums, they reveal many commonalities with the spoken discourse (more than e.g. blogs), in particular informal language. The informality may be noticed not only in the choice of words typical of the spoken discourse (interjections, slang, swearing) but also in occasional spelling mistakes, frequent lack of capitalization, neglected punctuation marks and diacritics, and, oftentimes, relaxed syntax (e.g. unfinished sentences, violated grammatical rules). The texts are also marked for spontaneity, the language is frequently emotional, the topics tend to shift abruptly, and they express highly subjective opinions ${ }^{6}$. These features are typically representative of the spoken discourse (Biber et al. 1999).

The data have been collected as part of the project on immigration discourse run by the University of Oslo. They have been teased out from online materials, largely from forums, yet some references will also be made to articles (and commentaries underneath) and blogs devoted to Polish immigration in Norway.

About one hundred fifty identified participants have been registered in our data under anonymous names (authors of posts) or as authors of blogs

6 Žižek (1997), however, indicates that language in forums and blogs lacks "subjectivization" users of a forum can intervene and disappear, leave a harsh comment and leave or come back later. They can escape the consequences of what they have said. Discussion threads can therefore quickly disintegrate. Additional issue is the proportion between participants and lurkers Johnson (2001) indicates that due to the imbalance between the two a forum can be less interactive than a face-to- face lecture or a conversation around the dinner table. 
and feature or opinion articles on immigration portals. The corpus, which currently amounts to ca. 17,000 tokens (ca. 130 online comments), is still growing7. The material which constitutes our corpus has not been copied automatically from online resources; rather, it has been manually carved out from online texts with the aim of creating a pool of data representing opinions expressed by Polish immigration living in Norway on Norway and Norwegians vs. Poland and Poles, with the view of revealing the sense of national identity of the Polish immigrants in Norway and the degree of their integration into the host society and culture. For this very reason, extended original passages were often omitted while compiling the corpus and what was ultimately considered as valid for the corpus were only fragments extracted from threads on forums, which were queried for carefully selected words (e.g. homeland, Polishness, nation, patriotism, etc.) that were expected to elicit the concept of national identity. Of the over 130 online comments found on the internet, which constitute our current immigration corpus, 25 were selected for this analysis. These were carefully selected out of the host of examples of impoliteness in order to show a representative sample of both the problems of identity of Polish immigrants in Norway and the type of impoliteness endorsed in the study. The corpus material contains narratives (for example, when discourse participants write about what they consider impolite in relation to some Poles or Norwegians) as well as non-narratives, in particular descriptions or sheer exclamations.

\subsection{Method of analysis}

The present study focuses on online discourse, where no face-to-face and immediate interaction is possible, and hence impoliteness is not readily observable on-site; rather, reactions result from reading a written message. This requires some adaptation of the existing typologies of impoliteness. For example, cases of exclusion, dissociation from others or ignoring somebody's presence are not directly discernible in the discourse situations under study, yet they are described by forum users as part of their own observations. Therefore, although vicarious and, thus, dwindled, they constitute important narrations or description of impoliteness germane to our study. Aside from these space and time constraints stemming from the lack of immediate communication, these

${ }^{7}$ The data presented in this section constitute of part of an on-going international project Discourses of the Nation and the National, led by the University in Oslo, Department of Literature, Areas Studies and European Languages. 
verbal expressions are also a good source of information and may convincingly provide samples of impolite behaviour. Of the ten types of positive impoliteness distinguished by Culpeper, the following have been found and are described in what follows: ignore, snub the other, fail to acknowledge the other's presence; exclude the other from an activity; dissociate from the other; be disinterested, unconcerned, unsympathetic; use obscure or secretive language; use taboo words, swear or use abusive or profane language; and call the other names, use derogatory nominations. The categories of negative impoliteness represented in our data include: frighten; condescend, scorn or ridicule - emphasise your relative power, be contemptuous, belittle the other; and explicitly associate the other with a negative aspect. These categories tend to overlap in some cases, hence the final typology used in this paper is simplified and it falls into three categories: (1) ignore and exclude; (2) dissociate and be unsympathetic (including examples illustrating the category of obscure or secretive language); and (3) call the other names and use derogatory nominations and vulgar words, condescend, scorn and ridicule.

Taking into account the fact that the examples presented below illustrate derogatory nominations used in the contexts of condescending remarks and explicit association of the other with a negative aspect, the third category merges positive impoliteness with negative impoliteness. Examples of swearing and abusive or profane language are present across the above-mentioned categories.

\subsection{Ignore and exclude}

The first category identified in our analysis of online discussions and narratives is "Ignore, snub the other - fail to acknowledge the other's presence". The fragment below presents a specific situation where Poles complain about unfair treatment at work in a Norwegian setting: they claim that they feel ignored and excluded. In light of the common perception of Norway as being famous for its egalitarianism and equality, such cases as the samples below run counter to one's expectations, revealing a different attitude of some Norwegians to immigrants, beyond the legal cover, especially to labour workers, and cast doubts on whether foreigners are treated in the same way as Norwegians. A handful of examples narrating unfair treatment and marginalization of, or even discrimination against Polish workers at work can be found in our corpus in relation to lower salary standards and poorer working conditions. In sample (1) Poles feel ignored by cooks at canteens and believe that Norwegians are treated more favourably. 
(1) A Norwegian comes last to the canteen but he talks to the cook and gets his pork chop first, even though Poles ordered the very same pork chop much earlier. $^{8}$ [MN.AK.16.15]

The second category of description used in the narratives under inspection, although closely related to the first one, and sometimes even overlapping, is "Exclude the other from an activity". The example below encodes both the category of exclusion, in the context of health problems, and the ignorance of trade unions. The topic of dismissing Poles while being on sick leave is discussed on forums in thematic threads devoted specifically to such cases ${ }^{9}$.

(2) I've been working in Norway for eight years. I have been on sick leave for 7 months and I have already had 2 meetings [with the boss]. Unfortunately, clearly the employer wants to get rid of me from the factory because he even doesn't try to propose a different post for me, instead he recommends dismissal. My health problems stem from the type of work I've been doing and that's why the best solution for me is a change of my workplace. I myself suggested three different posts I am qualified for. Unfortunately, I met with a refusal, and the main reason was, apparently, a lack of posts. To make the thing funnier, after a short period of time some posts were found for other people, and for one type of work 5 new employees were hired. I have had no conflict with the employer, and I have done my work honestly and diligently. I have no idea what the problem is and why it is easier for the employer to hire new people rather than let an experienced employer return to work. Before long I will have the third meeting and I'm afraid that since the employer has hired new employees for the posts I could have he will announce to me that there is no work for me and in agreement with NAV he will press on me to give up my job myself. I have contacted a person from trade unions, who works in our factory, but he turned out to be rather ineffective. I don't really know who I can ask for help. I feel discriminated and I think that my rights were violated. [FN.103.16]

More examples that challenge the Norwegian egalitarianism and equality are presented below. In fact, they expose the superficiality or inefficiency of the system, as can be observed in the narrative of exclusion of some Poles from the labour market. Poles are badly treated by their employers, civil servants and other Norwegians they encounter in their milieu on an everyday basis. This phenomenon, known as social and wage dumping, has been

\footnotetext{
${ }^{8}$ The translated versions of the original citations are somewhat polished, with some extra words occasionally added in square brackets to sketch the missing information from context and thus to enhance comprehensibility.

${ }^{9}$ For example the thread "Zwolninie na sykelmeldingu" or "Pracodawca ignoruje pracownika na zwolnieniu lekarskim" (forum-norwegia.pl)
} 
identified in sociological research as being tightly associated with Polish workers coming to Norway who often fall victims to illegal practices and social injustice. This happens due to, for example, no knowledge of the Norwegian labour market, the judicial system, the Norwegian language and their rights as workers. As a result, they are unable to pitch to the local labour market demands and, if need be, claim their rights on their own (see Anioł 2014 and Garstecki, 2014, for more details). Their ignorance of the Norwegian law and its labour market has a bearing on Polish workers' social and legal status. Reportedly, they are excluded from pay roll lists, they are refused their legal remuneration, dismissed from work, rejected by property owners in the property hiring process, etc.

(3) Poles in Norway have problems with the employers-they are badly treated, remuneration is not paid, [they have problems] with the neighbours, with exacting their laws in local governments, with renting a flat, children have problems with integration at school. [FN.F.30.07]

(4) Hello, I have a similar problem, it's about the directive, the agency cheats us and we are not paid the rates [which apply to other workers] in the factory, we are working in a fish factory, what can we do about it and where to submit [a complaint about] it. [MN.AK.15.13]

The issue of unpaid remunerations causes a lot of unrest and anxiety among Polish labour workers. The problem has recently been publicized in both Norwegian and Polish newspapers due to several well-known cases of Poles suing Norwegian employers ${ }^{10}$. The cases have also prompted heated discussions on Polish forums and portals run by Poles living in Norway ${ }^{11}$. Many cases were won (by Polish lawyers from Norway), which only proves that the complaints shared online may not be completely unwarranted ${ }^{12}$.

Exclusion is perceived as being based on the country of origin, that is, Norwegian perceptions and attitudes related to it. These attitudes are triggered by some overt "identity labels", such as names. This seems to be a pressing problem to the extent that some Poles consider taking a rather desperate step

\footnotetext{
10 For example: http://wyborcza.pl/1,76842,14331715,Upominasz_sie_o_swoje_prawa_zostajesz_ zwolniony_.html http:/www.dagbladet.no/2015/06/08/nyheter/innenriks/skatt/arbeidsliv/39522323/

${ }^{11}$ For example the thread "Polka wyrzucona z pracy za...mówienie po polsku" on the portal mojanorwegia.pl

12 More cases won by Garstecki Advokatfirma are described at: http://www.garstecki.no/news-imedia/.
} 
of changing their first or even second name as they find it difficult to get a job with a name which does not sound like Norwegian.

(5) Recently some friends of mine declared that they were going to change their first and last name because they had had great difficulties to find a job with personal data that sounded non-norwegian ${ }^{13}$. [FN.96.14]

(6) ...but the very fact that you have a non-Norwegian forename causes a situation that you become a person of second category. If you have also a nonNorwegian surname, you fall to a third category. Let's note that so far we have not come to any concrete facts, we don't know anything about a man, we don't know his age, education, past, we don't know what he looks like... We only know his forename and surname, both non-Norwegian and we are already people of a third category. [MN.AK.1.15]

Narratives about exclusion and discrimination based on the country of origin, lack of competence in Norwegian and a name that sounds foreign (Polish) is, unfortunately, confirmed by a Polish lawyer living in Norway, who openly admits, on the strength of his professional practice as a barrister ${ }^{14}$, that the problem of social and wage dumping, discrimination and breaking the law while hiring Polish immigrants is commonplace.

Strangely enough, Poles do not defer from complaining that they are discriminated against by other Poles, for example, employees in a job agency. There is even an informal saying circulating in the Polish community that the worst boss one can have is a Polish boss. Similar examples to (6) illustrate in-group divisions.

(7) in adecco a Polish woman looked through my papers, turned round and said that there was no work. [FN.49.07]

\subsection{Dissociate and be unsympathetic}

The third category according to Culpeper is "Dissociate from the other". Interestingly, this category found in online discussions/narrative may be illustrated by two types of dissociation.

The first example below describes a well-known fact that Polish immigration divides the community into two distinct groups: those who are hostile towards other Poles and those who are helpful and supportive.

\footnotetext{
13 All the translations preserve the features of the original text, i.e. there may be no capitalization, and erroneous or no punctuation marks.

14 See the full article at: http://wiadomosci.wp.pl/kat,1356,title,Polacy-w-Norwegii-drugakategoria-obywateli-Wraca-sprawa-Polaka-skazanego-za-pozar-w-Drammen,wid,17289727, wiadomosc.html?ticaid=116bcb 243
} 
Unfortunately, most comments online evidence the frequent phenomenon subscribing to the first case. As a result, some Poles dissociate themselves from the bothersome compatriots who are jealous, hostile and unsupportive, and, oftentimes, quarrelsome, vulgar and heavy drinkers (they are often called "polaczki"). Such framing conceptualizes two opposite camps and induces the identification of the author with outsiders relative to the criticized group, yet within the Polish immigration community. This dissociation is demonstrated, for example, by avoiding speaking Polish in public places or pretending not to understand Polish while in public places:

(8) Poland can be divided into poles and "polaczki". The latter are glad when a compatriot fails to achieve success abroad. They forgot why they left their country. Personally, I only encounter the latter [group of Poles] so when I hear Poles I never speak Polish and I do not admit that I'm Polish, because you never know who you come across...it is strange as other expats try to stick together. [FB.2.16]

Polish immigration that has managed to integrate into the Norwegian society and immerse into the Norwegian culture tends to dissociate from part of the Polish immigration community, especially from those who do not thrive on the labour market or have temporary jobs (usually as construction site workers) and often travel back to Poland (dubbed "polaczki", or "cebulaki"; see below for details).

(9) I am the one who is embarrassed to be Polish, unfortunately, that's why I am no longer [a Pole], I'm changing my surname,... I'm adding this for you, fuck, you simple Polish man, as you are not even able to realize what a simple thickhead you are. [MN.F.22.15]

The term frequently used in relation to Polish immigration in a pejorative way is "economic worker" ("pracownik zarobkowy"). It is used even by Poles themselves to describe their status, especially by those who do not feel integrated with the Norwegian society and perceive themselves as temporary workers and migrants, rather than permanent immigrants.

(10) You know what? Generally, I don't care what norway ${ }^{15}$ does with their immigrants as it's their problem. I'm here, as somebody has written, an economic worker (i.e. labour migration). [MN.AK.9.15]

\footnotetext{
${ }^{15}$ All punctuation and spelling mistakes in the translated texts (translations from Polish by: A.B.) are left in the English citations on purpose as they reflect the errors present in the original texts or language simplifications so typical of the informal language used in social media, which tends to imitate the spoken discourse.
} 
In a discussion on Polish emigration in the EU, Poles were described as "murzyni Europy" (the Negroes of Europe) by one of the forum users, which is telling and, regrettably, matches the general picture of a Polish emigrant seen as a skilled and cheap (often underpaid) blue collar worker (cf. the "Polish plumber"16). In a fragment below, a Polish employee describes her employer, who also treats Poles like sambos, a cheap labour, people who are exploited at work and have no labour rights.

(11) if Poles agree to work for 4 pounds then let them work their arse...shame, it's their choice...pity, as because of them we are perceived as the "Negros of Europe". [MN.7.15]

Many Poles are perceived as poor East European immigrants who come to Norway seeking better economic living conditions. With Poles entering the Norwegian labour market after the accession of Poland to the EU in 2004, the appearance of cheap labour on the Norwegian market (and even more on the British market) can be observed. To avoid social and wage dumping, in 2007 minimum wage in the construction branch was established in Norway (Garstecki 2014: 36), yet this has not changed the perception of a cheap immigration labour force by both Norwegians and other immigrants, including Poles. The bifurcation of the Norwegian labour market is still observed in its structure, with well-paid, safe, stable and secure jobs offered mainly to Norwegians and employees with high qualifications vs. mostly temporary, lowpaying jobs and lower standards accepted largely by temporary migrants, popular in such labour market segments as construction work and some services (caring, cleaning, repair, harvesting, processing) (Anioł 2014: 22).

The other group of comments, illustrating the category of dissociation, is targeted at Norwegians. As indicated by our data, Norwegians demonstrate explicitly that foreigners, including Poles, will always remain immigrants, i.e. second-class citizens, and that there is no hope for immigrants ever to be treated by the natives like compatriots. Here, the indigenous allocate Poles to the outsider group. Example (12) negatively evaluates Norwegians in relation to their attitude to work:

(12) Constantly, every day, they make it clear to us that we are only hirelings...:) It was difficult for me too but if you want to stay here then get used to it, ease up or go home... [MN.F.10.12]

\footnotetext{
16 The image of a "Polish plumber" was popularized in France in 2005 as a negative symbol of excessive cheap labour coming to France from Central Europe.
} 
(13) You are a Pole and Your child is also a Pole - NEVER, at least in the eyes of an average Norwegian, will you be a Norwegian. ALWAYS (in the perception of a Norwegian, a bit less in the case of a Swede) on the territory of the Kingdom [of Norway] will one be a "lower" category type - don't be taken in by the warm, insipid smile of the Norwegians, nor by the enforced formal equal rights (this must be admitted). [MN.F.14.15]

(14) has anybody seen a sweaty norwegian at work? I have! Not once! He climbed on the second floor and was really sweaty. They are not used to work. They have money and people who work for them. That's all one can say about them. [MN.F.3.15]

A reason for isolation of the Polish community from the Norwegian society is sometimes sought in the lack of knowledge of the Norwegian language, which is noticed by Poles themselves. Some Poles seem to refuse to learn Norwegian or to improve their competence in the language of the host country, which can be easily honed in practice while living in Norway. They are also reluctant to enhance their competence in English, which can be easily used as the language of everyday communication in Norway. As a result, with no communicative skills in either of the two languages used in Norway, they are doomed to isolation. This issue is often discussed online.

Interestingly, in line with the narratives shared by some forum users, Poles with no language skills tend to be more critical of Norway and Norwegians.

(15) indeed, most of the persons I met expresses negative opinions about Norwegians. I analysed who are those friends of mine and they are mainly working class people, they often work illegally, don't speak Norwegian at all, and their English is, at best, at pass mark level. So, their opinion stems from their own complexes and from the fact that they themselves isolate [from the society] through their lack of competence in any of the two languages. [FN.95.14]

(16) Ah well, what I meant was that we are treated badly at work $\odot I$ was in a situation when "norek" told me that I was there to bust [my arse] so to speak and that I was to do the worst job here and that he treated in this way all the foreigners who worked there, that for him we were the negroes $\otimes I$ went to see the boss about it but he did not see any problem in that, according to him everything is ok. [MN.F.9.12]

\subsection{Call the other names - use derogatory nominations and vulgar words}

The next category of positive politeness analysed in this paper is naming. This referential strategy is represented by a great number of examples 
in the corpus: it is usually realized through derogatory nomination and member categorization. Examples of nomination found in the corpus illustrate two cases: naming Norwegians and naming Poles.

On the whole, in the online discussions Poles notice a number of positive aspects in the Norwegians, their lifestyle, habits, traditions and mentality, and the comments in posts are replete with admiration and praise of a stereotypical Norwegian. However, since forums, Facebook, YouTube, etc., are places of unrestrained self-expression, where people can present their opinions freely, usually with little or no restrictions at all (moderators on forums occasionally delete some posts), severe criticism is not uncommon. When presented in the negative terms, Norwegians are described by the Internet users by resorting to several labels. Quite often, Norwegians at large are seen as "gbury" (boors, yobs) [MN.AK.1.14; FN.F.24.14], as well as "pyszałki" (coxcombs) [FN.F.24.14]. On a less critical note, they are conceived of as not too clever, uncomplicated and shallow as well as with double morality [FN.F.12.08], and rather cold and clammed, at least on the surface [NP.B.1.14].

Poles receive enormous criticism from their compatriots. The derogatory labels most often endorsed include the coined neologism "polonorki" as well as some other more frequently used terms, such as "polaczki", "buraki", "cebulaki" (or its diminutive "cebulaczki"). "Polaczki" is an ironic diminutive form of the word Poles (in original: Polacy), which has general negative connotations. The term is used to denote quarrelsome and petty-minded people, as well as rapacious and cunning, people who look down on other immigrants, referring to them by such terms as "ciapate" ("camel jockey", a racially-tinged slang term denoting Pakistanis, Indians or other dark-skinned immigrants). "Polaczki" are also qualified as racists, and the negative features of a typical "Polaczek" achieve the worst dimension in the case of those who have a relatively low social status:

(17) Unfortunately, the lower the social status of a "polaczek", the greater racist and conceited lout he is. [MN.AK.4.15]

Discussion about the national status and the feeling of affiliation to Polish immigration diaspora or the Norwegian society is often spotted with vulgarisms, which shows how much emotions are triggered by the problem of integration and the sense of national identity.

(18) And who the fuck do you think you are?....you polaczek [vocative]. [MN.F.5.15] 
"Buraki" (pl., beetroots) and "cebulaki" ( $p l$. , a neologism coined from the word "cebula", i.e. an onion) also imply negative associations: while a "burak" is an ill-mannered, not-too-intelligent bumpkin, "cebulak" also makes reference to bumpkins but in addition to that triggers an image of a person who is jealous and envious, and who is excessively mean and loutish.

(19) Polaczek cebulaczek-buraczek feels good when he insults others, calls them names, like ciapate and czarnuch [Nigro], he will be proud that he speaks Norwegian to his child at home and, generally speaking, he is more Norwegian than the Norwegians. [MN.F.4.15]

As for "polonorki", this term is a compound noun which combines "polo", associated with Poles (more precisely with "polaczek"), and "norki", associated with Norwegians. "Norek" is the worst epitomization of a Norwegian, one who does not pay wages on time and exploits his or her employees. The concept of "polonorek" has been described on one of the portals run by Poles in Norway ${ }^{17}$ where a number of citations from forums were adduced (mojanorwegia.pl and forum-norwegia.pl). "Polonorek" thus denotes a person who shares features of both nations - unfortunately, however, the worst features typically ascribed to Poles and Norwegians.

A Polonorek is a person who expresses strong contempt for Poles living in Norway as well as for Poland and Poles living in Poland, who tries to integrate with the indigenous (thus speaks Norwegian and meets only Norwegians) and glorifies Norway, and at the same time ostensively cuts off from his Polish roots, so that he tries "to be more Norwegian than the Norwegians". They are often representatives of the nouveau riche social class, who made a fortune through illegal business, often hiring compatriots and mistreating them or putting the skids under them. One forum user described "polonorek" as follows:

(20) Personally, to me Polonorek is a kind of nation-less person, neither Polish nor Norwegian - a kind of shit glued to a shoe of a Norwegian farmer. [MN.AK.16.14]

The material found in our corpus abounds in language soaked in insults. The categories that will be illustrated by our corpus material involve two types of negative impoliteness proposed by Culpeper, namely (1) condescend, scorn or ridicule (emphasize your relative power, be contemptuous, do not treat the other seriously, belittle the other) and (2) explicitly associate the other with a negative aspect (personalize, use the pronouns 'I' and 'you'). These categories

\footnotetext{
17 http://www.mojanorwegia.pl/czytelnia/kim-sa-polonorki-8976.html
} 
are merged into one as in most cases the empirical material is illustrative of both notions.

While participating in a heated discussion on Poles in Norway, some participants of a popular forum started to attack each other; in particular one of the forum users was aggressive and used vulgar words. Eventually, he switched into Norwegian as, obviously, he suspected that the other person he quarrelled with did not know Norwegian well enough (if at all) to be able to exchange arguments with him. The fact that he started to use Norwegian dissociates him from his interlocutor. The discussion was about the situation of Poles in the labour market. The type of negative impoliteness illustrated by the citation below is "condescend, scorn or ridicule". The author is contemptuous and emphasises his power over the addressee.

(21) Can you participate in this quarrel too. You are another dyed Pole. Who are you - another Polish Tosk [?]. Try to quarrel with me you "swine". [MN.F.9.15]

The interlocutor was labelled "swine" and "dyed Pole"; the former term is vulgar, while the latter encodes aggression towards Poles who pretend to be Norwegians and who tend to be cut off from their Polish identity. Other forum users evaluated this impoliteness explicitly by noticing that the two interlocutors were extremely impolite to each other. Crucially, one user made a digression on the matter at hand, speculating that if Poles treat other Poles living abroad with disrespect, this may be the reason, according to the forum user, why Norwegians show disrespect towards Poles living in Norway. This fragment also concurs with another category proposed by Culpeper as part of positive impoliteness, namely "Use obscure or secretive language - for example, mystify the other with jargon, or use a code known to others in the group, but not the target". Yet another example with the word swine shows how Poles express their severe criticism towards other Poles, for example when pinpointing such features as manifesting superiority to other nations.

(22) You are a classic Polish swine, who confirms the existence of a Polish swine, i.e. that there is such a creature in the world as the Polish swine that doesn't know who he is, and who would like to trample anybody who seems to be different, but he is not aware that these narrow hooves are of little avail because he is only slaughterhouse game. [MN.F.6.15]

The next fragment may illustrate one of the previous category of dissociation, yet it is ascribed to the category of calling names as it contains vulgar language and derogatory nominations ( $d o g$, burak). It also encodes the intention of being condescending to the interlocutor, which is achieved by explicit association 
of the interlocutor with a negative aspect using the pronoun "you" and the label „burak”.

(23) you dyed norwegian dog... you yourself are a burak from somewhere around Warsaw [MN.F.7.15]

Another example of negative impoliteness illustrated by the category of "condescend, scorn or ridicule" as well as "explicitly associate the other with a negative aspect" is connected with the notion of Polonorki. Polonorki trigger disrespect, disdain and contempt; the emergence of this group of Poles is evident in discussions about national identity. Severe criticism and strong emotions often entail the use of vulgarisms. Both polonorki and buraki/polaczki/cebulaki trigger criticism and strong emotions.

(24) if you don't want to be a Pole then I don't care...but don't offend other Poles you norwegian whore. [MN.F.3.15]

The next example of negative impoliteness is a post in which a Pole criticizes another forum user for boasting that s/he does not know Norwegian (or for pretending not to know it) at work, as that sheds bad light on the whole Polish immigration community. The author of the post occasionally switches into Norwegian while decrying the ignorant user. In this way, the author expresses dissociation from the Polish minority having a smattering of Norwegian language, by creating some "us" versus "them" division within the Polish immigration community. In the example below a condescending voice can be sensed, as well as scorn and ridicule, which would justify its classification in the "condescend, scorn and ridicule" category, according to Culpeper's typology. The author directly belabours the addressee with insults (damn pussy, monkey] and uses a very strong language.

(25) You are so "jevlig pingle" [damn pussy] if you don't know who that is then ask out as probably you are often called like that at work, or "ape" [monkey], he, he, he. [MN.F.8.15]

\section{Concluding remarks}

The impoliteness strategies presented above illustrate impoliteness expressed or shown by Poles towards other Poles living in Norway, by Poles towards Norwegians or by Norwegians towards Poles. Most interestingly, the majority of comments show impoliteness expressed by Poles towards other Poles, which is a striking observation suggesting that some Polish immigrants do not seem to feel the need to integrate and/or identify with their compatriots, or at least 
a part of them. In consequence, social ingroups and outgroups are created within the Polish immigration community, with comments targeted at "the others", mainly the other Poles, imbued with hatred and insulting language. Insulting language is a means of establishing distance between "us" and "them".

Given the online data of immigration discourse gathered in the project on national identity re/construction, the Polish diaspora in Norway seems to be integrated but only to some extent, i.e. within the subgroups that clearly emerge. Poles are divided into those who maintain their Polish identity and those who feel more Norwegian than Polish. A strong contempt is expressed in online discourse by a group of Poles for both those Poles who identify only with the Norwegians (the so-called Polonorki) as well as for those Poles who do not wish to take any measures to adjust to (integrate with) the host country (e.g. those who do not learn the Norwegian language, are critical of Norway and the Norwegians, etc.).

Very strong emotions are unlocked in the discussions of identity and integrity found in our online material. Semi-public discussions of identity issues are frequently coupled with strong emotions, and these are related to various impoliteness realizations. The anonymity of the internet certainly promotes impunity of its users, which in turn provokes unrestrained, blatantly impolite or even vulgar verbal behaviours expressing debasing, disparaging or vituperative attitudes. The corpus of online data briefly presented in this study is only a case in point, as it is replete with copious examples of impolite language and explicit description of impolite behaviour.

\section{REFERENCES}

Angouri, J., and T. Tseliga. (2010). "You have no idea what you are talking about!" From e-disagreement to e-impoliteness in two online for a. Journal of Politeness Research. Language, Behaviour, Culture 6/1, 57-82.

Androutsopoulos, J. (2006). Introduction: sociolinguistics and computer-mediated communication. Journal of Sociolinguistics 10/4, 419-438.

Anioł, W. (2014). Poles in the Norwegian labour market: benefits and challenges. In: M. MrozińskaKruk (ed.). Polish community in Norway. Opportunities and challenges, Oslo, 15-24.

Biber, D. et al. (1999). Longman Grammar of spoken and written English. Harlow: Longman.

Bousfield, D. (2008). Impoliteness in Interaction. Amsterdam: John Benjamins.

Bousfield, D. (2010). Researching impoliteness and rudeness: issues and definitions. In: M.A. Locher and S.L. Graham (eds). Interpersonal pragmatics. Berlin: Mouton de Gruyter, 101-134. 
Bouvier, G. (2015). What is a discourse approach to Twitter, Facebook, YouTube and other social media: connecting with other academic fields? Journal of Multicultural Discourses 10/2, 149-162.

Crystal, D. (2001). Language and the Internet, Cambridge: CUP.

Culpeper, J. (1996). Towards an anatomy of impoliteness. Journal of Pragmatics 25/3, 349-367.

Culpeper, J., D. Bousfield and A. Wichmann. (2003). Impoliteness revisited: with special reference to dynamic and prosodic aspects, Journal of Pragmatics 35/10-11, 1545-1579.

Culpeper, J. (2005). Impoliteness and entertainment in the television quiz show: The Weakest Link. Journal of Politeness Research: Language. Behavior and Culture 1/1, 35-72.

Culpeper, J. (2011). Impoliteness: Using language to cause offence. Cambridge: CUP.

Culpeper, J. (2016). Impoliteness strategies. In: A. Capone and J. L. May (eds). Interdisciplinary studies in pragmatics, culture and society, Cham: Springer, 421-445.

De Fina, A. (2003). Identity in narrative: A study of immigrant discourse Amsterdam: John Benjamins.

Dikotter, F. (ed.). (1997). The construction of racial identities in China and Japan: historical and contemporary perspectives. University of Hawaii Press.

Donath, J. S. (1997). Identity and deception in the virtual community. In: P. Kollock and M. Smith (eds). Communities in cyberspace, London: Routledge, 27-58.

Garcés-Conejos Blitvich, P. (2010). The YouTubification of politics, impoliteness and polarization. In: R. Taiwo (ed.). Handbook of research on discourse behavior and digital communication: Language structures and social interaction, Hershey: IGI Global, 540-563.

Garstecki, S. (2014). Poles in Norway - from a judicial point of view. In: M. Mrozińska-Kruk (ed.). Polish community in Norway. Opportunities and challenges, Oslo: Ministry of Foreign Affairs, 34-42.

Graham, S. L. (2007). Disagreeing to agree: Conflict, (im)politeness and identity in a computermediated community. Journal of Pragmatics, 39/4, 742-759.

Hart, C. (2011). Force-interactive patterns in immigration discourse: a cognitive linguistic approach to CDA, Discourse \& Society, 22/3, 269-286.

Hart, C. (2015). Viewpoint in linguistic discourse: space and evaluation in news reports of political protests, Critical Discourse Studies, 12/3, 238-260.

Herring, S. C. (2007), A faceted classification scheme for computer-mediated discourse, "Language@Internet", v. 4. Retrieved from: http://www.languageatinternet.org/articles/ 2007/761 (Accessed October 25, 2016)

Hilbert, M. (2009). The maturing concept of e-democracy: from e-voting and online consultations to democratic value out of jumbled online chatter. Journal of Information Technology \& Politics 6, 87-110.

Johnson, S. (2001). Emergence: the connected lives of ants, brains, cities, and software. New York: Scribner.

Kádár, D. and M. Haugh. (2013). Understanding Politeness. Cambridge: CUP.

KhosraviNik, M. (2010). The representation of refugees, asylum seekers and immigrants in British newspapers: a critical discourse analysis. Journal of Language and Politics 9/1, 1-28.

KhosraviNik, M. (2014). Immigration discourses and critical discourse analysis: dynamics of world events and immigration representations in the British Press. In: C. Hart and P. Cap (eds). Contemporary Critical Discourse Studies. London and New York: Bloomsbury, 501-519. 
Krzyżanowski, M. and R. Wodak. (2009). The politics of exclusion: debating migration in Austria. New Brunswick: Transaction Publishers.

Krzyżanowski, M. (2010). The Discursive Construction of European Identities: A multilevel approach to discourse and identity in the transforming European Union. Frankfurt am Main: Peter Lang.

Martínez Lirola, M. (2013). Immigrants going back home: an analysis of the discursive representation of the return plan for immigrants in three Spanish newspapers. In: M. Martínez Lirola (ed.). Discourses of immigration in times of economic crisis: A critical perspective, Newcastle upon Tyne: Cambridge Scholars, 1-27.

Locher, M. A. (2010). Introduction: politeness and impoliteness in computer-mediated communication. Journal of Politeness Research 6/1, 1-5.

McCarthy, M. (1993). Spoken discourse markers in written texts. In: J.M. Sinclair, M. Hoey and G. Fox (eds). Techniques of Description: Spoken and written discourse. A festschrift for Malcolm Coulthard. London: Routledge, 170-182.

Nishimura, Y. (2008). Japanese BBS websites as online communities: impoliteness perspectives. Language@Internet 5/3. Retrieved from: http://www.languageatinternet.org/articles/ 2008/1520 (Accessed October 25, 2016)

Norrick, N. R. and A. Spitz. (2008). Humor as a resource for mitigating conflict in interaction. Journal of Pragmatics 40, 1661-1689.

Olszewski, E. (ed.). (2011). Polacy w Norwegii (1940-2010). Toruń: Marszałek.

Pawlak, M. (2012). Transformation and reproduction of national identity among Polish immigrants in Norway. Poznań: unpublished $\mathrm{PhD}$ diss.

Raymond, G. G. and T. Modood. (eds.). (2007). The Construction of Minority Identities in France and Britain. Basingstoke: Palgrave.

Reisigl, M. and R. Wodak. (2001). Discourse and Discrimination: Rhetorics of racism and antisemitism, London: Routledge.

Richardson, J. E. and M. Colombo. (2014). Race and immigration in far- and extreme-right European political leaflets. In: C. Hart and P. Cap (eds). Contemporary Critical Discourse Studies, London: Bloomsbury, 521-543.

Terkourafi, M. (2008). Toward a unified theory of politeness, impoliteness, and rudeness. In: D. Bousfield and M. Locher (eds). Impoliteness in language. Berlin and New York: Mouton de Gruyter, 45-74.

Upadhyay, S. R. (2010). Identity and impoliteness in computer-mediated reader responses. Journal of Politeness Research Language, Behaviour, Culture 6/1, 105-127.

Van Dijk, T. A. (1984). Prejudice in discourse. An analysis of ethnic prejudice in cognition and conversation. Amsterdam \& Philadelphia: John Benjamins.

Van Dijk, T. A. (1987). Communicating racism: ethnic prejudice in thought and talk. Newbury Park, CA: Sage.

Van Dijk, T. A. (1991). Racism and the Press, London: Routledge.

Van Dijk, T. A. (2015). Racism in the press. In: N. Bonvillain (ed.). Handbook of linguistic anthropology, London: Routledge, 384-392.

Van Leeuwen, T. and R. Wodak. (1996). Legitimizing immigration control: a discourse-historical analysis, Discourse Studies 10/1, 83-118.

Watts, R. J. (1989). Relevance and relational work: linguistic politeness as politic behavior, Multilingua, 8/2-3, 131-166.

Wodak, R. (1996). Disorders of discourse. London: Addison Wesley. 
Yates, S. J. (1996). Oral and written linguistic aspects of computer conferencing: a corpus-based study. In: S.C. Herring (ed.). Computer-mediated communication: linguistic, social and cross-cultural perspectives, Amsterdam: John Benjamins, 29-46.

Žižek, S. (1997). The plague of fantasies. London: Verso.

\section{Internet sites:}

http://oslo.msz.gov.pl/resource/0c005e6b-1a8e-4184-a454-deabde543fad:JCR

http://forum-norwegia.pl

http://wyborcza.pl/1,76842,14331715,Upominasz_sie_o_swoje_prawa_zostajesz_zwolniony_.ht ml http://www.dagbladet.no/2015/06/08/nyheter/innenriks/skatt/arbeidsliv/39522323/

http://mojanorwegia.pl

http://www.garstecki.no/news-i-media/.

http://wiadomosci.wp.pl/kat,1356,title,Polacy-w-Norwegii-druga-kategoria-obywateli-Wraca-sprawaPolaka-skazanego-za-pozar-w-Drammen,wid,17289727,wiadomosc.html?ticaid=116bcb

http://www.mojanorwegia.pl/czytelnia/kim-sa-polonorki-8976.html 